\title{
Lifelong learning and influencing on the quality of the society
}

\author{
Juhani Anttila, Academician, M.Sc. (Electrical Engineering) \\ International Academy for Quality (IAQ) \\ Aalto University Department of Industrial Engineering and Management, Espoo, Finland \\ Rypsikuja 4, 00660 Helsinki, Finland \\ juhani.anttila@telecon.fi, www.QualityIntegration.biz
}

\author{
Kari Jussila, M.Sc. (Physical Electronics), M.Sc. (Economics) \\ Aalto University Department of Industrial Engineering and Management, Espoo, Finland \\ P.O. Box 15500, FI-00076 Aalto, Espoo, Finland \\ kari.jussila@aalto.fi
}

Keywords: Quality, Lifelong learning, Education, Society, Elite

\begin{abstract}
Individual people are the key actors in all societies directly or indirectly through different organizations and institutions. Lifelong learning of people and its influence on the development of the societies are considered in this paper particularly from the quality point of view. In this context, we also refer to inventing, which is the cognate phenomenon of learning. Professional quality approach has proven beneficial in all areas of our societies. Education and learning should not be any exceptions. However, many cases demonstrate that performed quality measures do not deliver promises or are unsatisfactory. Also questions of the quality of education and the quality of society are most often dealt with inconsistently and ambiguously. In order to avoid ambiguity, we refer in this research to the basics of the professional quality. This conceptual research offers a consistent quality perspective on the lifelong learning of people and the organizational learning in order to improve the quality of the society. As a special aspect, we want to bring out the points of view of the strong influential individuals and the elite of the society. With the professional quality approach, our aim is to generate ideas for empirical studies, to address views of practical challenges for the education discipline as well as organizations, and to build a bridge between education and the quality expertise.
\end{abstract}

\section{Learning in a broad sense, and quality diffusion in societies}

A person's lifelong learning ${ }^{i}$ during his/her entire existence, as an individual and as a member of organizations and societies takes place through formal and informal educational and societal processes of gaining or acquiring knowledge or skills. Our societies have a great variety of these possibilities for education and learning for individuals through their lifetime. Learning also provides driving force for inventing that is the prerequisite of innovation ${ }^{\text {ii }}$.

Organizations and societies learn through their individual members' collaboration and learning. Learning of the organization is aimed at the purposes of the organization, and it is organized by the management and the business system. Learning of the society takes place through the influence and activity of many different independent individuals and organizations in the society. Learning individual, learning organization, and learning society are very different learning domains, and the challenging question is how to ensure quality in these cases.

All learning activities have crucial influence on the development of our societies as a whole. In this context a society may be considered as a local, nation- or country-wide, regional, or global entirety, or as an issue-specific group of people. Members of the society are independent but interactive actors, they have distinct identities and development status, and consist of citizens, visitors, institutions, private companies, and organizations of public civil service and not-for-profit third sector. An organization is a person or group of people that has its own functions with responsibilities, authorities and relationships to achieve its objectives ${ }^{\text {iii }}$. Individuals institute the society, and individuals are influenced and developed by the instituted society ${ }^{\text {iv }}$. Ultimately, the individuals are the core of the societies. 
Individuals of the society are not equal. Always a certain minority of people has bigger passion and influence on the society and its development. In practice, the influence can mean both good and bad consequences $^{\mathrm{v}}$ with regard to the society and its different individual members.

Quality of the society in general implies a good, well-functioning and well-developing, or excellent society for all of its members. The society and its quality develop through activities and interactions of people directly or via different organizations and institutions. This development may happen according to the incremental evolution or radical revolution. Societal quality improvement arises as the result of large scale learning and innovation ${ }^{\text {vi }}$. We call this quality diffusion.

\section{A professional quality approach}

General professional standardized ${ }^{\mathrm{vii}}$ quality concepts and principles are well established and practiced in most of the countries, and used in millions of different organizations. It is highly justified to use them in the field of education and learning, too. In any case, the quality topic has largely been pointed up in educational discussions but the used quality phraseology and practices are inconsistent.

The most central general concepts, quality and quality management $(\mathrm{QM})$, provide the foundation for the professional quality approach. Quality is defined as the degree to which the object fulfills the needs and expectations of all interested parties ${ }^{\text {viii }}$. In the educational context, the object consists of all outputs of the educational organizations. An educational organization has many interested parties, but the teacher and learner are the most important ones, and they have very different needs and expectations. QM implies coordinated activities to direct and control the organization and its processes with regard to quality ${ }^{\mathrm{ix}}$.

The key challenge for quality is to identify the real needs and expectations. The individuals' needs and expectations cannot be standardized. They are related to persons' different stages of life cycle, quality of life expectations, and their world-views. In particular, some individuals in the society have greater aims and aspirations. According to Johnston ${ }^{\mathrm{x}}$ : "If you treat everyone the same, what varies is satisfaction. To achieve equal satisfaction, you must vary treatment". Educational needs are shifting from 'learning to know and do' to 'learning to be and live together' societal aspects. Challenges that become to overcome consist of multi-disciplinary dimensions of skills and knowledge.

People's needs for learning may considerably change during their lifetime. That may mean unlearning or relearning. Needs for the organizational learning come from the purpose and targets of the organization as defined by the top management. People's learning during their working life is a remarkable part of their lifelong learning. The whole society's needs for learning cannot be dictated by anybody on behalf of others. However, strong societal and international authorities may guide the development of education in societies. European Union has recently recognized that the educational systems do not meet the requirements of the labor market ${ }^{\mathrm{xii}}$.

According to the above mentioned standard definition, the quality of a society at large means the degree to which the society fulfills the needs and expectations of all individuals of the society directly or indirectly via different organizations and also those of certain significant parties outside the society. The traditional QM concepts and methodologies have been developed for organizations and hence they are not applicable for the societal networks. The quality of the society develops through diffusion, but not through QM as it happens in the organizations.

\section{Learning providing and receiving processes}

Learning is the co-created result of interacting processes of providing and receiving learning. Both the teacher and the learner should perceive this teaching/learning event valuable. We understand the archetype of the teaching/learning phenomenon as interacting human processes of knowledge creating. This was already the situation at the Plato's Academy.

Process management ${ }^{\mathrm{xiii}}$ and risk management ${ }^{\mathrm{xiv}}$ are the professional prerequisites for quality realization in the educational organizations. Learning takes place in certain environments through 
teaching material (HW - Hardware), human interaction (MW - Manware), and information technological means (SW - Software) (Fig. 1).

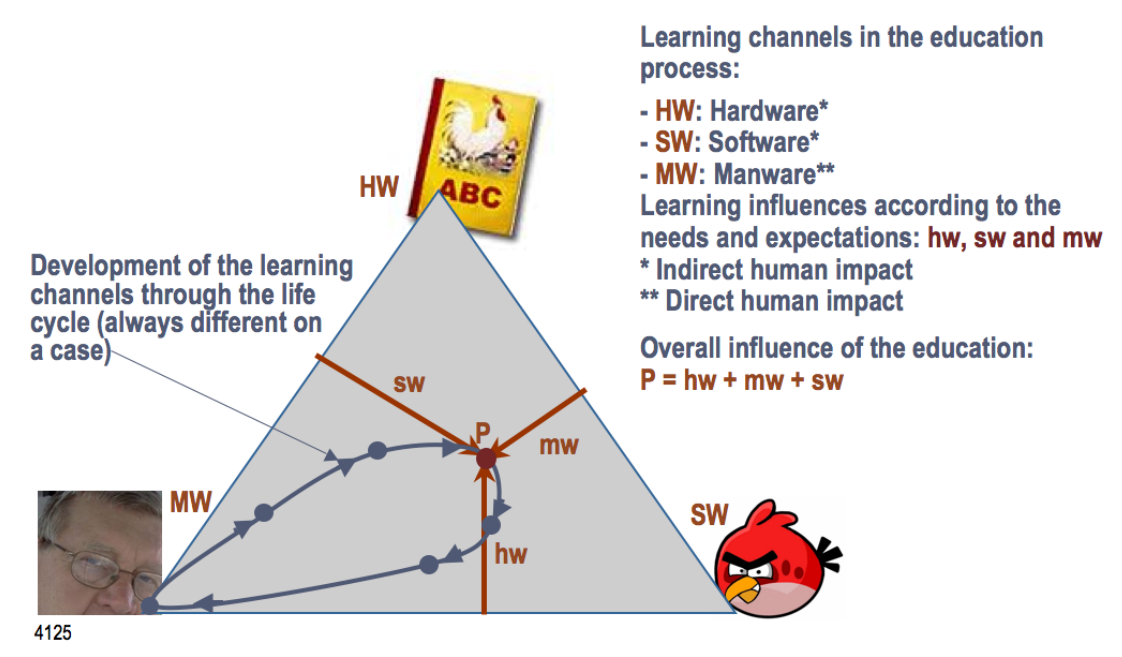

Figure 1. Providing learning in the education processes through different learning channels during the lifelong learning, which begins and ends with the direct human touch ${ }^{\mathrm{Xv}}$. (The SW figure is the Agry Bird of Rovio Entertainment Ltd. ${ }^{\mathrm{xvi}}$ )

Traditionally learning is seen as a formal educational activity but the majority of learning takes place informally ${ }^{x v i i}$ and is supported by social interactive means. We should question the old learning theories $^{\text {xviii xix }}$, and now connectivism, interacting and collaborating are at the core of learning. This has also created a lot of new learning environments and practices mainly based on social, informal and open learning ${ }^{\mathrm{xx}}$ xxi xxii xxiii xxiv xxv xxvi .

\section{Learning of individuals, organizations, and societies}

Each person has his/her own personality based limiting performance level (PLPL) influenced by the rational, emotional, spiritual and cultural factors, and the actual operational performance level (POPL) ${ }^{\text {xxvii }}$ xxviii influenced by the mood and operational situation and improves incrementally through learning. The PLPL may change at certain opportune time moments of significant emotional experience.

Lifelong learning develops through the person's living as a member of society through his/her lifecycle ${ }^{\mathrm{xxix}}$ from the pre-birth stage to death. Our approach is based on the scientific thinking, fundamental teaching/learning archetype, and the professional quality concepts, and it can provide the universal quality model for learning at all life stages.

In organizations, awareness, attitudes, skills and competences develop through the organized learning of the personnel in the organization. Incremental learning is related to certain particular skills, for instance related to innovation. Radical large-scale breakthrough change ${ }^{\mathrm{xxx}}$ is a particular transformation process ${ }^{\mathrm{xxx}}$ and often requires a crisis ${ }^{\mathrm{xxxii}}$. Transformations are initiated and managed from the strategic (top management) level of the organization by decisive actions and include consistent learning. Organizational learning aims at personal mastery, mental models, shared vision, team learning and systems thinking within the organization ${ }^{\text {xxxiii }}$.

People act and make decisions privately and in their working teams in situations, in which causality is poorly understood, uncertainty exists, and people have different beliefs and personal biases. Knowledge workers - actually today all employees and business leaders - have to negotiate in order to understand what they face. If people want to create shared meaning, they need to talk about their experience in close proximity to its occurrence and have common platforms for conversation. This means on the job learning.

Leadership language has an important role in the organizations ${ }^{\text {xxxiv }}$. An organization is a living organism. Language defines the environment in which the organization lives. Narrowing language 
increases efficiency but the organization becomes unable to adapt to changes in its environment. Organizational growing is possible only if the organization learns new language from outside.

Societies are scale-free networks ${ }^{\mathrm{xxxv}}$. Multiple Win / Win principle is the key requirement for learning and sustained success among the networking partners. Strong network actors (hubs) keep the network alive, and quality of the network facilitates its growth. These actors include two categories of the societal elite ${ }^{\mathrm{xxxvi}}$ :

- People that are superior in terms of ability or qualities to the rest of the society

- People that have the most power and influence in a society, especially on account of their wealth or privilege

\section{Evaluating the performance of educational organizations and the quality of society}

Performance evaluations and measurements ${ }^{\text {xxxvii }}$ are the key issues of the established QM. Professional quality methodologies include strategic self-assessment and operational process evaluations of the organizations and their results. Such practices are not widely used in the field of education. However, many evaluation models have been developed for formal education and learning

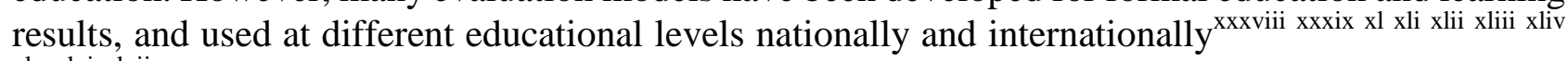
xlv xlvi xlvii . These approaches are not consistently compatible and may be confusing from the quality point of view.

Measurement is a challenging issue ${ }^{x l v i i i}$ for creating information and knowledge. Metrology ${ }^{\text {xlix }}$ is the science of measurement, and its vocabulary covers the generally accepted terms and definitions. According to Deming ${ }^{1}$ information is not knowledge. Knowledge comes from theory. Without theory, there is no way to use information from the measurements. Also in the field of education, the performance measurements should be based on the general scientific and professional principles.

Well-established practices for evaluating the whole societies from the overall quality point of view are not available. However, there are a lot of published information on the society evaluations and comparisons that are very fragmented into many specialized local, regional, and national topics, including aspects of municipality operations, social capital, social fragility and risks, environmental issues, nature, ecology and sustainable development, competitiveness, culture and cultural values, language, wealth, family issues, public participation and human relationships, creativity and innovations, peace, freedom, happiness and quality of life, etc. Typically the professional quality viewpoints have not been much emphasized in these cases.

\section{National approaches and references from Finland}

The Finnish education system is often referred to for the purpose of benchmarking ${ }^{\text {li }}$. Our basic education is defined in the national education plans that have developed during the recent 100 years from ethical objectivism to ethical relativism ${ }^{\text {lii }}$. The quality topic is not considered explicitly in these plans. Finland has stayed apart from the global education reform movement (GERM) ${ }^{\text {liii liv }}$ that has emerged since the 1980s and become adopted throughout the world.

Recently we have explored new educational practices, e.g. positive psychology and character strength pedagogy ${ }^{1 v}$, and learning through applying gamification ${ }^{\text {lvi }}$ in education. Now a lot of information technology is being introduced to education although it is also questioned ${ }^{\text {lvii }}$. Right now, the time of recession sets challenges for the educational investments and threatens the development.

One of the basic principles of the Finnish education is that all people have equal access to the same high-quality education and training ${ }^{\text {viii }}$, and the same opportunities to education are available to all citizens irrespective of their ethnic origin, age, wealth or where they live. Education is also free at all levels. That also means that in Finland we have no elite based on the national educational system. Also, due to the satisfactorily functioning democracy and minimal corruption all citizens have thus equal opportunities to influence in the society. 
We have, however, recognized an unfavorable or even dangerous development in the strategic foresight planning ${ }^{\text {lix }}$ for the future of the whole society or nation ${ }^{\text {lx }}$. The foresight work has evolved into a discussion and decision-making of the new elite of experts, policy-makers and politicians, top representatives of the trade unions, business sectors and the cultural life, and the citizens' capabilities have been ignored. Also the choice of words and terms, which differ from the ordinary use of language, highlight the specificity of the work, and even extraneous "trolls" network. This development is inconsistent with the principles of democracy. A long term reaction to this development could be education and learning to more inventive and collaborative knowledge lxii $^{\text {in }}$ based society and the effective use of the new interactive communicational means that also have direct positive influence on the creativity, inventions ${ }^{\text {lxiii }}$, societal capital, and the quality of society.

\section{Summary}

A lot of study results is available, and extensive worldwide discussion of various future challenges of lifelong learning and its relation to the quality and development of the society as a whole are

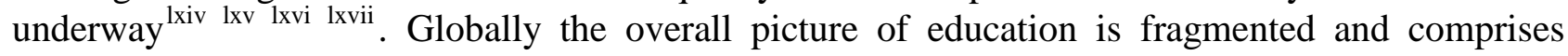
contradicting views. However, education and learning, especially incorporated with innovation, are in general recognized crucial from the societies' development point of view. Quality discipline may refine this intention with proven professional concepts and practices. This paper aims at building a bridge between education and quality expertise for multidisciplinary professionalism and mutual learning.

\section{References}

${ }^{\mathrm{i}}$ Lifelong Learning Council Queenland Inc, What is lifelong learning? http://www.llcq.org.au/01_cms/details.asp?ID=12 (2014)

ii J. Anttila, Quality and innovation, EOQ2013 Congress Workshop on board Tallinn-Helsinki http://www.qualityintegration.biz/HailInnovation.html (2013)

iii ISO, ISO 9000 standards series, Quality management systems, ISO, Geneva (2005/8/9)

${ }^{\text {iv }}$ C. Castoriadis, Pouvoir, la politique, l'autonomie (1978) (In Finnish, Magma, Karisto 1997)

${ }^{v}$ R. B. Cialdini, Influence: The psychology of persuasion, William Morrow and Co. Ltd. (2006)

${ }^{v i}$ P.A. Gloor, The stupidity of crowds and the wisdom of the swarm, http://www.datenundgesundheit.ch/wp-content/uploads/2014/04/Daten_Gesundheit_Gloor.pdf (2014)

${ }^{\text {vii }}$ ISO, ISO 9000 standards series, Quality management systems, ISO, Geneva (2005/8/9) viii ibid.

ix ibid.

${ }^{\mathrm{x}}$ K. Johnston, Busting bureaucracy. Business One Irvin (1993)

${ }^{x i}$ UNESCO, Learning: The treasure within, UNESCO, Paris France (1996)

xii The European Parliament, Report on rethinking education, http://www.europarl.europa.eu/sides/getDoc.do?pubRef=-//EP//NONSGML+REPORT+A7-2013-0 314+0+DOC+PDF+V0//EN EU (2014)

xiii J. Anttila and K. Jussila, An advanced insight into managing business processes in practice, Total Quality Management \& Business Excellence, Volume 24, Issue 7-8 (2013)

${ }^{x i v}$ ISO, ISO 31000 Risk management - Principles and guidelines, ISO, Geneva, Switzerland (2009)

${ }^{\mathrm{xv}} \mathrm{J}$. Anttila and K. Jussila, Aiming at competitive products and delighted customers in the time of recession, in Quality against recession proceedings of the Symposium in Rovinj, Croatia (2013)

${ }^{x v i}$ Rovio Entertainment Ltd., Rovio Learning, http://www.rovio.com/en/our-work/learning (2015)

${ }^{x v i i}$ J. Cross, Informal learning - the other $80 \%$, http://www.jaycross.com/wp/2013/04/informal-learning-the-other-80/ (2003) 
${ }^{x v i i i}$ G. Siemens, Connectivism: A learning theory for the digital age, http://www.itdl.org/journal/jan_05/article01.htm (2005)

${ }^{{ }^{x i x}}$ S. Downes, The Buntine Oration: Learning Networks, http://www.downes.ca/post/20 (2004)

${ }^{x x}$ R. Cole, J.J. Kemple and M. D. Segeritz, Assessing the early impact of school of one: Evidence from three school-wide pilots, https://files.nyu.edu/RANYCS/public/media/SO1-Report-06-20-12.pdf (2012)

${ }^{\mathrm{xxi}}$ Educause, Things you should know about flipped classrooms, https://net.educause.edu/ir/library/pdf/ELI7081.pdf (2012)

${ }^{x x i i}$ L. Vanderkam, Blended learning, http://www.philanthropyroundtable.org/file_uploads/Blended_Learning_Guidebook.pdf (2013)

${ }^{x x i i i}$ S. Mitra, Build a school in the cloud, http://www.ted.com/talks/sugata_mitra_build_a_school_in_the_cloud.html (2013)

${ }^{x x i v}$ V. Jones and J.H. Jo, Ubiquitous learning environment, http://www.ascilite.org.au/conferences/perth04/procs/pdf/jones.pdf (2004)

${ }^{\mathrm{xxv}} \mathrm{R}$. Schuman, The king of MOOCs abdicates, http://www.slate.com/articles/life/education/2013/11/sebastian_thrun_and_udacity_distance_learnin $\mathrm{g}$ is unsuccessful_for_most_students.html (2013)

${ }_{\mathrm{xxvi}}$ B. Corcoran, Disney 'Connected learning' aims to infuse games with learning, https://www.edsurge.com/n/2013-02-06-disney-connected-learning-aims-to-infuse-games-with-lear ning (2013)

${ }_{\text {xxvii }}$ C. Møller, Personal quality, TMI, Odense Denmark (1987)

${ }^{x x v i i i}$ H.J. Harrington, Theory H, IBM Technical report TR 02.976 San Jose USA (1982)

${ }^{x x i x} \mathrm{~T}$. Armstrong, The twelve stages of the human life cycle, http://www.institute4learning.com/stages_of life.php (2008)

${ }^{\mathrm{xxx}}$ W.E. Deming, The new economics. MIT. Cambridge MA (1993)

${ }^{x x x i}$ D. Butcher, P. Harvey and S. Atkinson, Developing businesses through developing individuals, Cranfield School of Management, Cranfield England (1997)

xxxii J. Anttila, Business crises, threat and opportunity for quality management. EOQ Congress, Dubrovnik Croatia (2009)

${ }^{x x x i i i}$ P. Senge, C. Roberts, B. Ross and A. Kleiner, The fifth discipline fieldbook, Nicholas Brealey

Publishing Ltd, London UK (1995)

xxxiv Sun Microsystems: The little grey book. http://pangaro.com/littlegreybook.pdf (2002)

${ }^{\mathrm{xxxv}}$ A. Barabási, Linked: How everything is connected to everything else and what it means for business, science, and everyday life. Plume Books. New York (2003)

xxxvi Oxford Dictionary,

http://www.oxforddictionaries.com/definition/english/elite? searchDictCode=all

xxxvii J. Anttila and K. Jussila, 'You get what you measure. Or not?' Challenges for fact-based quality management, in Quality for Excellence proceedings of the International Symposium on Quality in Osijek, Croatia (2011)

${ }^{x x x v i i i}$ UNESCO, General education system quality analysis/diagnosis framework (2012), http://www.unesco.org/new/fileadmin/MULTIMEDIA/HQ/ED/pdf/GEQAF__English.pdf

${ }_{\text {xxxix }}$ OECD, The Programme for International Student Assessment (PISA), http://www.oecd.org/pisa/aboutpisa/ (2013)

${ }^{\mathrm{xl}}$ Boston College, TIMSS/PIRLS, http://timssandpirls.bc.edu/\# (2014)

xli The EIU, The learning curve, http://thelearningcurve.pearson.com (2014)

xlii NIST, Baldrige education criteria for performance excellence, http://www.nist.gov/baldrige/publications/education_criteria.cfm (2013)

${ }^{x l i i i}$ European Commission, The Bologna process and the European higher education area, http://ec.europa.eu/education/policy/higher-education/bologna-process_en.htm (2014) 
${ }^{x l i v}$ EQAVET, The European quality assurance in vocational education and training, http://www.eqavet.eu/gns/about-eqavet/welcome.aspx (2014)

${ }^{\mathrm{xlv}}$ ISO/PC 288 Educational organizations management systems, http://www.iso.org/iso/home/standards_development/list_of_iso_technical_committees/iso_technic al_committee.htm?commid=4960304 (2014)

${ }^{\bar{x} l v i}$ E. McArdle, What happened to the Common Core? Harvard Graduate School of Education, http://www.gse.harvard.edu/news/ed/14/09/what-happened-common-core (2014)

${ }^{\mathrm{xlvii}}$ S.D. Feliciano, NP 4512:2012 - A new Portuguese management system standard fostering quality, innovation and technology in vocational education and training,

http://papers.efquel.org/index.php/tqm-book/article/view/89/29 (2012)

xlviii J. Anttila and K. Jussila, 'You get what you measure. Or not?' Challenges for fact-based quality management, in Quality for Excellence proceedings of the International Symposium on Quality in Osijek, Croatia (2011)

xlix International Organization of Legal Metrology, OIML V 2-200, International vocabulary of metrology, Geneve (2010) http://www.oiml.org/publications/V/V002-200-e10.pdf

${ }^{1}$ M. Walton, Deming management at work, Perigee Books, New York (1990)

${ }^{\text {li }}$ P. Sahlberg, Finnish Lessons 2.0: What can the world learn from educational change in Finland?

Teachers College Press, Columbia University New York USA (2015)

lii L. Launonen, Ethical thinking in Finnish school's pedagogical texts from the 1860s to the 1990s, University of Jyväskylä, Jyväskylä,

https://www.jyu.fi/ajankohtaista/arkisto/2000/10/tiedote-2007-09-18-14-42-00-658059 (2000)

liii J. Graham (editor), GERM Global education reform movement. Professional voice, http://www.aeuvic.asn.au/2631_pv_9_3_issuu.pdf (2013)

${ }^{l i v}$ P. Sahlberg, Global educational reform movement is here!

http://pasisahlberg.com/global-educational-reform-movement-is-here/ (2014)

${ }^{1 \mathrm{v}}$ M. Seligman, R. Ernst, J. Gillham, K. Reivich and M. Linkins, Positive education: positive psychology and classroom interventions, Oxford Review of Education Vol. 35, No. 3, http://www.ppc.sas.upenn.edu/positiveeducationarticle2009.pdf (2009)

${ }^{1 \text { vi }}$ Badgeville, Gamification, http://badgeville.com/wiki/Gamification (2015)

lvii K. Kashmanian, The impact of computers on schools: Two authors, two perspectives, http://technologysource.org/article/impact_of_computers_on_schools/ (2000)

${ }^{1 \text { viii }}$ Finnish National Board of Education, Finnish education in a nutshell, http://www.oph.fi/download/146428_Finnish_Education_in_a_Nutshell.pdf (2012)

lix The World Economic Forum, Strategic foresight, http://www.weforum.org/community/strategic-foresight (2015)

${ }^{\mathrm{lx}}$ A. Kettunen, Conceptions of time, the individual and society in Finnish future politics, University of Jyväskylä, Jyväskylä, Finland (2014)

${ }^{1 x i} \mathrm{C}$. Mooney, Internet trolls really are horrible people,

http://www.slate.com/articles/health_and_science/climate_desk/2014/02/internet_troll_personality_ study_machiavellianism_narcissism_psychopathy.html (2014)

${ }^{1 x i i}$ K. Tammets, Meta-analysis of Nonaka \& Takeuchi's knowledge management model in the context of lifelong learning, Journal of Knowledge Management Practice, Vol. 13, No. 4, http://www.tlainc.com/articl319.htm (2012)

${ }_{\text {xiii }}$ P.A. Gloor, The stupidity of crowds and the wisdom of the swarm,

http://www.datenundgesundheit.ch/wp-content/uploads/2014/04/Daten_Gesundheit_Gloor.pdf (2014)

${ }^{\text {lxiv }}$ UNESCO, Teaching and learning: Achieving quality for all, The EFA global monitoring report, Paris http://unesco.nl/sites/default/files/dossier/gmr_2013-4.pdf?download=1 (2014) 
${ }^{1 x v}$ I. Cunningham, Why schooling is a major contributor to the crisis, http://college.selfmanagedlearning.org/wp-content/uploads/2013/09/why-schooling-is-a-major-contr ibutor-to-the-crisis.pdf (2010)

${ }^{1 x v i}$ E.A. Hanushek and L. Wößmann, Education quality and economic growth, The International Bank for Reconstruction and Development / The World Bank,

http://siteresources.worldbank.org/EDUCATION/Resources/278200-1099079877269/547664-1099 079934475/Edu_Quality_Economic_Growth.pdf (2007)

${ }^{1 x v i i}$ A. Peterson, J. Lexmond, J. Hallgarten and D. Kerr, Schools with soul: A new approach to spiritual, moral, social and cultural education, RSA

http://www.thersa.org/_data/assets/pdf_file/0003/1540758/Schools-with-soul-REPORT.pdf (2014) 